little stratigraphical importance; my own studies (1958) of the Hexactinellida of the Chalk of England show, instead, a definite sucession of faunas. Judged by comparison, the sponge bed fauna has no distinctly Turonian elements. Many of its traceable species are forms which seem first to occur in England in the zone of $M$. cor-anguinum; there are, however, species of several genera which are typical of the higher Senonian, such as Coeloptychium Goldfuss and Lepidospongia F. A. Roemer. Further, the glauconitic chalk above the main sponge band-and sometimes the sponge band itself, which seems to be slightly diachronous-yields several species which are otherwise typical of the I. lingua sponge beds of S.E. Yorkshire. There is thus a suggestion that parts of this glauconitic chalk are of $O$. pilula age: that is, slightly younger than the authors cited suggest.

When these suggestions based on sponges were made, I had not obtained any determinable examples from the conglomerate of N.E. Antrim. Its outcrop at Murlough Bay has now yielded two specimens of Rhizopoterion cribrosum (Phillips). This is a species recorded in England by Rowe (1900, p. 360, as Ventriculites cribrosus) from as low as the I. labiatus zone. My own collecting indicates, however, that lower Senonian and earlier records refer properly to distinct, though partly congeneric, forms; the true $R$. cribrosum seems only to occur from the zone of Marsupites upward, and mainly above it. Its Irish distribution is similar. The species is common in the glauconitic chalk of eastern Antrim, either in the part above the main sponge band, or sometimes in the sponge band itself where this contains supposed I. lingua elements. It is present also in the higher glauconitic chalk and mulatto of the Belfast area, of $O$. pilula and G. quadrata age, and in various localities in the typical White Limestone of the $B$. mucronata zone. Its local range is thus mainly upper Senonian, and its earliest occurrence at a level which is possibly as high as the zone of $O$. pilula.

The occurrence of this sponge at Murlough Bay thus suggests that part at least of the conglomerates is of middle or upper Senonian age, no older than the glauconitic chalk in which $R$. cribrosum occurs to the south, and distinctly younger than the maximum age suggested by the Torr Head Lewesiceras.

\title{
REFERENCES
}

ANDERSON, F. W. 1957. In Summary of Progress of the Geological Survey of Great Britain and the Museum of Practical Geology for the Year 1956, $50-52$.

Hume, W. F. 1897. The Cretaceous Strata of County Antrim. Quart. Journ. Geol. Soc., liii, 540-606.

McGugan, A., 1957. Upper Cretaceous Foraminifera from Northern Ireland. Journ. Palaeont., xxxi, 2, 329-349.

REID, R. E. H., 1958. Remarks on the Upper Cretaceous Hexactinellida of County Antrim. Ir. Nat. Journ., xii, 236-243 and 261-268.

Rowe, A., 1900. The Zones of the White Chalk of the English Coast. IKent and Sussex. Proc. Geol. Assoc., xvi, 289-368.

DePartment of Geology,

R. E. H. REID.

THE QUEEN'S UNIVERSITY OF BeLFAST,

Belfast, Northern IRELAND.

8th December, 1958.

\section{AFRICAN EROSION SURFACES}

SIR,--In a recent letter to the Geological Magazine, Pallister (1958) has referred to a spirited controversy on the origin of certain erosion surfaces in north-east Belgian Congo between Lepersonne $(1949,1956 a, 1956 b, 1958)$ and the writer $(1954 a, 1954 b, 1956,1958)$. During the course of the controversy, I (1958, pp. 369-370) referred to a paper by Pallister (1956) in which 
he showed the probable correlation of a bevel in the Masaka District of Uganda known as the Koki Surface with the Buganda Erosion Surface (mid-Tertiary). Controversy, in turn, had developed on the correlation of the Koki Surface (McConnell, 1955, 1957; Pallister, 1956).

In the statement that Pallister quoted from my latest paper on African erosion surfaces $(1958$, p. 378), I may have read more into Pallister's work than was warranted. However, I was referring to the problem of the Koki Surface and its correlation; which $I$ had detailed in a preceding part of the paper (1958, pp. 369-370). This reference was made to show that Lepersonne's (1956b) correlation of an "aplanissement fin-Crétacé PI (Congo belge)" with the Koki Surface of Uganda was questionable. In the statement that Pallister quoted, unfortunatley I did not clarify the issue, and I assume the responsibility for not doing so.

Pallister's calling attention to this matter is appreciated, and I take the opportunity to correct the record.

\section{REFERENCES}

LEPERSONNE, J., 1949. Le fossé tectonique Lac Albert-Semliki-Lac Edouard. Ann. Soc. Géol. Belg., lxxii, 3-91.

1956a. Les surfaces d'érosion des hauts plateaux de l'intérieur de l'Afrique centrale-analyse critique d'une étude de M. R. V. Ruhe. Acad. Roy. Sci. Col., Bull. nouv. sér. ii, 4, 596-621.

1956b. Les aplanissements d'érosion du nord-est du Congo belge et des régions voisines. Acad. Roy. Sci. Col., Mem. iv, 1-108.

1958. Mise au point concernant la note de M. R. V. Ruhe, intitulée : "Erosion surfaces of the Ituri, Belgian Congo. Reply to J. Lepersonne." Acad. Roy. Sci. Col., Bull. nouv. sér. iv, 2, 384-407.

McConnell, R. B., 1955. The erosion surfaces of Uganda. Col. Geol. Min. Res., v, 425-428.

_- 1957. Erosion surfaces in Uganda. Geol. Mag., xciv, 171-173.

Pallister, J. W., 1956. Slope form and erosion surfaces in Uganda. ibid., xciii, 465-472.

1958. African erosion surfaces. ibid., xcv, 513.

RUHE, R. V., 1954a. Erosion surfaces of Central African interior high plateaus. Publ. del'I.N.E.A.C., Bruxelles, sér. sci. 59.

1954b. Geology of the soils of the Nioka-Ituri area, Belgian Congo in Carte des sols et de la végétation du Congo belge et du Ruanda-

Urundi, 4-Nioka (Ituri). Publ. de l'I.N.E.A.C., Bruxelles.
1956. Landscape evolution in the high Ituri, Belgian Congo. Publ. de l'I.N.E.A.C., Bruxelles, sér. sci. 66, 108.

1958. Erosion surfaces of the Ituri, Belgian Congo. Reply to J. Lepersonne. Acad. Roy. Sci. Col., Bull. nouk sér. iv, 2, 360-383.

State College,

R. V. RUHE.

NEW MEXICO,

U.S.A.

December, 1958. 